\title{
PENGARUH MOTIVASI DAN PENGETAHUAN UU NO.5 TAHUN 2011 TENTANG AKUNTAN PUBLIK TERHADAP MINAT MAHASISWA AKUNTANSI MENGIKUTI PENDIDIKAN PROFESI AKUNTANSI (PPAk)
}

\author{
$\underline{\text { Rita Kusumastuti }} \mathbf{1}^{\mathbf{1}}$ \\ yiyit.yita@ymail.com \\ $\underline{\text { Indarto Waluyo }}{ }^{2}$
}

Fakultas Ekonomi Universitas Negeri Yogyakarta

\begin{abstract}
ABSTRAK
Penelitian ini bertujuan untuk mengetahui Pengaruh Motivasi dan Pengetahuan Undang-Undang No.5 tahun 2011 tentang Akuntan Publik terhadap Minat Mahasiswa Akuntansi Mengikuti Pendidikan Profesi Akuntansi. Pemilihan sampel menggunakan metode proportionate stratified sampling. Jumlah sampel penelitian sebanyak 102 sampel. Teknik analisis data yang digunakan adalah uji asumsi klasik meliputi uji normalitas, uji multikolinearitas, uji linieritas dan uji heteroskedastisitas. Analisis data untuk menguji hipotesis adalah dengan menggunakan teknik analisis regresi sederhana dan analisis regresi berganda. Berdasarkan hasil penelitian menunjukan bahwa (1) Motivasi Karir berpengaruh positif dan signifikan terhadap Minat Mahasiswa Akuntansi Mengikuti PPAk, dibuktikan $\mathrm{t}_{\text {hitung }}$ 5,289 $>\mathrm{t}_{\text {tabel }}$ 1,984 (2) Motivasi Mengikuti USAP berpengaruh positif dan signifikan terhadap Minat Mahasiswa Akuntansi Mengikuti PPAk, dibuktikan $t_{\text {hitung }} 4,528>t_{\text {tabel }}$ 1,984 (3) Motivasi Kualitas berpengaruh positif dan signifikan terhadap Minat Mahasiswa Akuntansi Mengikuti PPAk, $\mathrm{t}_{\text {hitung }}$ 5,287 > $\mathrm{t}_{\text {tabel }}$ 1,984 (4) Motivasi Ekonomi berpengaruh positif dan signifikan terhadap Minat Mahasiswa Akuntansi Mengikuti PPAk, dibuktikan $t_{\text {hitung }} 4,544>t_{\text {tabel }}$ 1,984 (5) Pengetahuan UU.No.5 tahun 2011 tentang Akuntan Publik berpengaruh positif dan signifikan terhadap Minat Mahasiswa Akuntansi Mengikuti PPAk, dibuktikan $\mathrm{t}_{\text {hitung }} 2,417>\mathrm{t}_{\text {tabel }}$ 1,984 (6) Motivasi Karir, Motivasi Mengikuti USAP, Motivasi Kualitas, Motivasi Ekonomi, Pengetahuan Undang-Undang No.5 tahun 2011 tentang Akuntan Publik berpengaruh positif terhadap Minat Mahasiswa Akuntansi Mengikuti PPAk, dibuktikan $F_{\text {hitung }}$ sebesar 9,907 > $F_{\text {tabel }}$ sebesar 2,309.
\end{abstract}

Kata Kunci: Motivasi, Pengetahuan Undang-Undang No.5 Tahun 2011, Minat Mengikuti PPAk

\section{ABSTRACT}

The aims of this research are to know influences the effect of motivation and knowledge of the Act No. 5 of 2011 on Public Accountants on Accounting Students Following Interests Accounting Profession. The selection of samples using proportionate stratified sampling method. Total sample as many as 102 samples. The data analysis technique used is the classical assumption includes normality

\footnotetext{
${ }^{1}$ Alumni Prodi Akuntansi Fakultas Ekonomi Universitas Negeri Yogyakarta

${ }^{2}$ Staf Pengajar Jurusan P. Akuntansi Fakultas Ekononi Universitas Negeri Yogyakarta
} 


\section{JURNAL NOMINAL / VOLUME II NOMOR II / TAHUN 2013}

test, multicollinearity, heteroscedasticity test and linearity test. Data analysis was to test the hypothesis by using regression analysis technique simple and multiple regression analysis. Based on the results of the study showed that (1) Motivation Career positive and significant effect of the Interests Accounting Students Following PPAk, evidenced by the value of 5,289 $t>t$ table value of 1.984 (2) Motivation Following USAP positive and significant effect of the Interests Accounting Students Following PPAk, evidenced by the value of 4.528 t count $>t$ table value 1.984 (3) Motivation Quality positive and significant effect of the Interests Accounting Students Following PPAk, proved the value of $5.287 t>t$ table value 1.984 (4) Economic Motivation positive and significant effect of the Interests Accounting Students Following PPAk, proved the value of $t 4.544>t$ table value 1.984 (5) Knowledge UU.No.5 Public Accountant in 2011 on a positive and significant effect on interest Accounting Students Following PPAk, proved the value of $2.417 t>t$ table value 1.984 (6) Career Motivation, Motivation Following USAP, Motivation Quality, Economic Motivation, Knowledge Act No. 5 of 2011 on Public Accountants jointly positive effect on student Interests Following Accounting Accounting Profession, this is evidenced by Fcount value 9.907> 2.309 Ftable.

Keywords: Motivation, Knowledge Act No. 5 of 2011, followed PPAk Interests

\section{A. PENDAHULUAN}

\section{Latar Belakang Masalah}

Mahasiswa yang meraih gelar Sarjana Ekonomi khususnya akuntansi banyak memiliki alternatif untuk bekerja. Menurut Astami (2001) dalam Nugroho (2011), setelah menyelesaikan pendidikan di jurusan akuntansi, pertama dapat langsung bekerja di suatu instansi, berwirausaha, perusahaan atau lembaga lainnya. Kedua, dapat melanjutkan pendidikan akademik ke jenjang lebih tinggi, baik S2 akuntansi ataupun lain bidang. Ketiga, dapat melanjutkan ke Pendidikan Profesi Akuntansi (PPAk).

Pendidikan Profesi Akuntansi adalah pendidikan tambahan pada pendidikan tinggi setelah program sarjana Ilmu Ekonomi dalam program studi akuntansi berdasarkan Surat Keputusan Menteri Pendidikan Nasional Republik Indonesia Nomor 179/U/2001 tanggal 21 November 2001 tentang Penyelenggaraan Pendidikan Profesi Akuntansi. PPAk diselenggarakan di perguruan tinggi sesuai dengan persyaratan, tatacara dan kurikulum yang diatur oleh Ikatan Akuntan Indonesia(IAI). Lulusan pendidikan profesi akuntansi berhak menyandang gelar profesi Akuntan (disingkat Ak).

Sebelum SK tersebut dikeluarkan pada tahun 2011, pemberian gelar akuntan didasarkan pada Undang-undang No.34 Tahun 1954 yang 
menyatakan bahwa gelar akuntan diberikan pada lulusan perguruan tinggi yang ditunjuk pemerintah dan atau perguruan tinggi negeri yang memenuhi syarat untuk menghasilkan akuntan atas proses pendidikan yang diberikan. Mahasiswa yang telah lulus S1 akuntansi di Universitas Indonesia (UI), Universitas Negeri Sumatra Utara (USU), Universitas Gajah Mada (UGM), Universitas Airlangga (UNAIR), Universitas Padjajaran (UNPAD), Universitas Brawijaya (UNIBRAW) dan STAN secara otomatis akan memperoleh gelar sarjana akuntansi, untuk memperoleh gelar sarjana akuntansi, mahasiswa dari perguruan lainnya harus memenuhi Ujian Negara Akuntansi.

Menurut Machfoed (1998) dalam Iqbal (2011) proses pemberian gelar akuntansi yang diskriminatif tersebut memiliki dua kelemahan yaitu timbulnya diskriminatif pemberian gelar akuntan dan tidak meratanya tingkat profesionalisme para akuntan di dunia kerja. Berdasarkan hal itu organisasi professional akuntansi (Ikatan Akuntan Indonesia) dan Departemen Pendidikan dan Kebudayaan melalui Dirjen Dikti meninjau kembali peraturan yang berlaku untuk menghasilkan akuntan profesional. Melalui Surat Keputusan Menteri Pendidikan Nasional Republik Indonesia Nomor 179/U/2001 dan Surat Keputusan Mendiknas No.180/P/2001 tentang Pengangkatan Ahli Persamaan Ijazah Akuntan maka Pendidikan Profesi Akuntansi di Indonesia dapat terlaksana.

Dengan adanya surat keputusan tersebut pendidikan akuntansi di Indonesia secara resmi memiliki pendidikan berbasis profesi. Dalam penelitian Samiaji tahun 2004 disebutkan bahwa selama ini pendidikan akuntansi hanya menitikberatkan pada akademis saja sehingga aspek pendidikan profesi yang sangat penting terkesan tidak mendapat perhatian. Pendidikan Profesi Akuntansi sudah mulai dijalankan sejak September 2002. Dengan dimulainya Pendidikan Profesi Akuntansi maka gelar akuntan tidak hanya diperoleh dari PTN tertentu yang telah ditunjuk oleh dinas pendidikan. Dengan begitu diharapkan mahasiswa yang memiliki gelar akuntan dapat benar-benar profesional dan dapat bersaing dengan akuntan asing yang masuk ke Indonesia. 


\section{JURNAL NOMINAL / VOLUME II NOMOR II / TAHUN 2013}

Perkembangan zaman yang begitu pesat mengakibatkan semakin terbukanya akuntan asing yang berpraktik di Indonesia. Melihat kondisi ini apakah saat ini akuntan Indonesia siap untuk menghadapi serbuan akuntan asing yang masuk di Indonesia. Menanggapi tantangan tersebut, Dewan Pengurus Nasional IAI (Ikatan Akuntan Indonesia) Yusuf Halim (2012) menilai ada indikasi ketidaksiapan para akuntan Indonesia.

"Untuk menghadapi tantangan itu, para akuntan butuh persiapan, butuh proses sehingga dibutuhkan kesadaran para akuntan Indonesia untuk mempersiapkan diri," Rabu siang (16/5/12) usai memberikan materi dalam seminar "Reshaping The accountancy Profession -opportunies dan Chelengges for Indonesia “ yang diselenggarakan IAI di Jakarta.

Untuk mempersiapkan kedatangan akuntan asing di Indonesia maka akuntan perlu meningkatkan kualitas agar tidak kalah bersaing dengan akuntan asing. Mahasiswa lulusan akuntansi dapat melanjutkan pendidikan profesi akuntansi agar kualitas di bidang akuntansi semakin meningkat dan dapat bersaing di era global.

Mereka yang telah menempuh Pendidikan Profesi Akuntansi akan semakin berpeluang untuk berkarir sebagai auditor pemerintahan, auditor internal, akuntan sektor publik, akuntan manajemen, akuntan pendidik, akuntan perpajakan, akuntan keuangan maupun akuntan sistem informasi. Mahasiswa yang mengikuti Pendidikan Profesi Akuntansi berhak mengikuti Ujian Sertifikasi Akuntan Publik, yang merupakan syarat untuk mendapatkan ijin praktik mendirikan sebuah KAP. Dengan adanya ujian ini diharapkan calon akuntan tidak hanya mahir secara teknis namun mahir secara profesional, lulusan Pendidikan Profesi Akuntansi nantinya akan memiliki kualitas yang lebih tinggi dibandingkan dengan yang tidak mengikuti Pendidikan Profesi Akuntansi.

Pendidikan Profesi Akuntansi memiliki peran penting untuk karir seorang akuntan di masa depan, namun minat lulusan S1 akuntansi masih cukup rendah untuk mengikuti PPAk. Sebagai contoh dalam penelitian Riani dkk (2008) disebutkan bahwa minat lulusan S1 Akuntansi Fakultas Ekonomi Universitas Indonesia (FEUI) untuk mengikuti PPAk masih rendah. 


\section{JURNAL NOMINAL / VOLUME II NOMOR II / TAHUN 2013}

Penyelenggaraan PPAk FEUI dari tahun 2003 sampai tahun 2008 telah menghasilkan 650 lulusan yang menjadi akuntan beregister, dari angka sebanyak itu yang merupakan lulusan akuntansi FEUI hanya 25 orang (4\%).

Dari segi kuantitas, akuntan publik di Indonesia kalah jauh dengan negerinegeri tetangga. Indonesia hanya memiliki 920 akuntan publik dan hanya 800 orang yang berpraktek karena selebihnya cuti praktik atau tidak boleh praktik karena sedang mendapatkan sangsi. Hal ini terlihat aneh karena Indonesia yang memiliki 230 juta jiwa penduduk dan memiliki banyak lulusan mahasiswa akuntansi hanya memiliki 920 akuntan publik. Jika dibandingkan dengan negara di ASEAN, jumlah akuntan publik di Indonesia tergolong rendah. Singapura yang hanya memiliki jumlah penduduk sekitar 5 juta jiwa mempunya Akuntan Publik sekitar 15.000 orang, Filipina yang memiliki jumlah penduduk 88 juta jiwa mempunyai Akuntan Publik sebanyak 15.000 orang, Thailand dengan jumlah penduduk 66 juta jiwa mempunyai Akuntan Publik sebanyak 6.000, dan Malaysia dengan jumlah penduduk 25 juta jiwa mempunyai akuntan Publik sebanyak 2.500 orang, Vietnam dengan jumlah penduduk 85 juta jiwa mempunyai akuntan publik 1.500 orang. Jumlah akuntan publik yang berpraktik di Indonesia 64\% nya sudah di atas 50 tahun dan hanya $10 \%$ yang berusia 30-40 tahun. Hal ini menunjukkan kurangnya regenerasi sekaligus minat kalangan muda untuk masuk dalam profesi akuntan publik. Padahal jumlah perusahaan di Indonesia yang perlu diaudit semakin banyak. (www.iai.com). Berkurangnya regenerasi untuk masuk dalam profesi akuntan publik tersebut dikarenakan yang ingin berkarir di akuntan publik harus melaksanakan Pendidikan Profesi Akuntansi agar terdaftar sebagai akuntan beregister.

Minat mengikuti Pendidikan Profesi Akuntansi dapat dipengaruhi oleh beberapa faktor. Faktor itu antara lain, motivasi karir, ekonomi, mencari ilmu, mengikuti USAP, lama pendidikan (Riany 2008). Secara umum orang yang berminat mengikuti Pendidikan Profesi Akuntansi memiliki motivasi.

Seseorang pasti menginginkan karir, gaji yang besar dalam pekerjaannya. Menurut Stole (1976) dalam Ellyana Benny dan Yuskar (2006) menyatakan bahwa karir di KAP merupakan suatu karir yang memberikan penghargaan 
secara finansial dan pengalaman kerja yang bervariasi, untuk mendapatkan karir yang bagus harus memiliki keahlian atau kualitas diri. Seseorang dapat meningkatkan kualitas dengan mengikuti PPAk, dengan mengikuti itu peluang untuk menjadi seorang akuntan terbuka lebar. Setelah mengikuti PPAk akan semakin berpeluang untuk berkarir sebagai auditor, akuntan pendidik, akuntan pajak, dan semua itu memberikan penghargaan finansial yang cukup besar. Jadi motivasi ekonomi, karir, kualitas dapat mempengaruhi minat seseorang mengikuti PPAk.

Tidak semua mahasiswa Akuntansi memiliki pengetahuan UU No.5 tahun 2011 tentang Akuntan Publik, padahal pengetahuan Undang-Undang No.5 Tahun 2011 tentang Akuntan Publik dapat mempengaruhi Minat Mahasiswa Mengikuti PPAk, jika sesorang memahami tentang akuntan publik maka mahasiswa semakin berminat mengikuti PPAk karena hal itulah salah satu syarat untuk menjadi seorang akuntan publik.

Berdasarkan latar belakang tersebut penulis termotivasi untuk meneliti mengenai minat mahasiswa akuntansi untuk mengikuti Pendidikan Profesi Akuntansi. Penelitian ini dimotivasi Widyastuti dkk (2004) telah meneliti faktor yang mempengaruhi mahasiswa untuk mengikuti PPAk dengan variabel motivasi karir, motivasi ekonomi, motivasi kualitas, dan tingkat pendidikan. Penelitian Riani Nurainah Lisnasari, Fitryani (2008) meneliti tentang faktor faktor yang mempengaruhi minat mahasiswa akuntansi untuk mengikuti pendidikan profesi akuntansi. Berdasarkan uraian di atas penulis akan

melakukan penelitian lebih lanjut mengenai: "Pengaruh Motivasi Dan Pengetahuan Undang-Undang No.5 Tahun 2011 Tentang Akuntan Publik Terhadap Minat Mahasiswa Akuntansi untuk Mengikuti Pendidikan Profesi Akuntansi”.

\section{B. KAJIAN LITERATUR}

1. Pengertian Minat

Menurut kamus Besar Bahasa Indonesia minat dapat diartikan sebagai suatu perhatian, kesukaan (kecenderungan hati) pada sesuatu yang diinginkan. Pengertian minat menurut Djaali (2007:122) adalah 
kecenderungan hati yang tinggi terhadap sesuatu. Secara terminologi, minat adalah keinginan, kesukaan, dan kemauan terhadap suatu hal. (Sukardi. 1993:46) minat adalah suatu perangkat mental yang terdiri dari kombinasi, perpaduan, dan campuran dari perasaan, harapan, prasangka, takut, cemas dan kecenderungan-kecenderungan lain yang bisa mengarahkan individu kepada pilihan tertentu.

Menurut Muhibbin Syah (2004:136) minat (interest) berarti kecenderungan dan kegairahan yang tinggi atau keinginan yang besar terhadap sesuatu. (Slameto. 2010:180) minat adalah suatu rasa lebih suka dan rasa ketertarikan pada suatu hal atau aktivitas, tanpa ada yang menyuruh. Minat pada dasarnya adalah penerimaan akan suatu hubungan antara diri sendiri dengan sesuatu di luar diri. Semakin kuat atau dekat hubungan tersebut semakin besar minat.

Menurut Widyastuti (2004) minat adalah keinginan yang didorong oleh suatu keinginan, setelah melihat, mengamati dan membandingkan serta mempertimbangkan dengan kebutuhan yang diinginkannya. Minat adalah kecenderungan hati yang tinggi terhadap sesuatu

Dari beberapa definisi minat diatas dapat ditarik kesimpulan minat adalah keinginan yang kuat yang timbul dari diri seseorang karena adanya ketertarikan, kesukaan untuk mencapai tujuan tertentu.

2. PPAK

Pendidikan Profesi Akuntansi merupakan pendidikan yang diselenggarakan setelah menempuh pendidikan S1 dengan tujuan untuk mendapatkan gelar Akuntan (Ak). Hal ini sesuai dengan isi SK Mendiknas No. 179/U/2001, perihal pemberian gelar Akuntan (Ak), yaitu sejak tanggal 31 Agustus 2004 seluruh lulusan S1 Jurusan Akuntansi tidak lagi bergelar Akuntan (Ak). Dasar hukum pelaksanaan PPAk adalah Naskah Kerjasama Ikatan Akuntan Indonesia dan DIKTI, SK Mendiknas 179/U/2001 tentang Penyelenggaraan Pendidikan Profesi Akuntansi. Adanya Pendidikan Profesi Akuntansi diharapkan dapat meningkatkan kualitas pendidikan khususnya akuntansi. 


\section{JURNAL NOMINAL / VOLUME II NOMOR II / TAHUN 2013}

3. Motivasi

Menurut Nana Syaodih Sukmadinata (2003:61) motivasi adalah kekuatan yang menjadi pendorong kegiatan individu tersebut. Kekuatan tersebut menunjukkan suatu kondisi dalam diri individu yang menggerakkan individu tersebut melakukan kegiatan pencapaian sesuatu tujuan.Malayu S.P Hasibuan (2003:95) mendefinisikan motivasi adalah pemberian daya penggerak yang menciptakan kegairahan kerja seseorang agar mereka mau bekerjasama, efektif dan terintegrasi dengan segala upayanya untuk mencapai kepuasan. Secara etimologis, Winardi (2002:1) menjelaskan istilah motivasi (motivation) berasal dari perkataan bahasa latin, yakni movere yang berarti menggerakkan, kemudian diserap dalam bahasa inggris menjadi motivation berarti pemberian motif, penimbulan motif atau hal yang menimbulkan dorongan atau keadaan yang menimbulkan dorongan.

Menurut Widyastuti dkk (2004) motivasi diartikan sebagai dorongan. Dorongan atau tenaga tersebut merupakan gerak jiwa dan jasmani untuk berbuat, sehingga motivasi merupakan suatu tenaga yang menggerakkan manusia untuk bertingkah laku di dalam perbuatannya yang mempunyai tujuan tertentu.

Menurut Sudarwan Danim (2004:2) mengatakan motivasi adalah kekuatan, dorongan, kebutuhan, semangat, tekatan atau mekanisme psikologi yang mendorong orang untuk mencapai prestasi tertentu sesuai apa yang dikehendaki. Motivasi yang ada pada seseorang akan mewujudkan suatu perilaku yang diarahkan pada tujuan mencapai sasaran kepuasan.

Berdasarkan definisi tersebut dapat disimpulkan bahwa motivasi merupakan dorongan yang ada di dalam diri manusia untuk melakukan suatu tindakan yang memiliki tujuan tertentu, yang merupakan penyebab terjadinya suatu aktivitas serta motivasi ditandai oleh reaksi-reaksi untuk memperoleh tujuan. 


\section{JURNAL NOMINAL / VOLUME II NOMOR II / TAHUN 2013}

\section{Kerangka Berfikir}

a. Pengaruh Motivasi Karir terhadap Minat Mahasiswa Akuntansi Mengikuti PPAk

Karir merupakan suatu keahlian atau professional seseorang di bidang ilmunya yang dinilai berdasarkan pengalaman kerja yang akan memberikan kontribusi kepada organisasi. Pilihan karir merupakan ungkapan diri seseorang, karena pilihan karir menunujukkan motivasi seseorang, ilmu dan kepribadian seseorang. Motivasi karir adalah dorongan yang timbul dalam diri seseorang untuk meningkatkan kemampuan pribadinya dalam rangka mencapai kedudukan,jabatan, karir yang lebih baik dari sebelumnya.

Institusi pendidikan mempunyai pengaruh besar terhadap perkembangan karir seorang akuntan. Auditor yang mempunyai latar belakang pendidikan profesional akuntansi membutuhkan waktu yang lebih sedikit untuk dipromosikan menjadi auditor senior dan atau manajer. Sebagai sebuah pendidikan profesi, PPAk dapat memberikan kontribusi positif untuk mahasiswa yang ingin mengembangkan kemampuan \& keahliannya di bidang akuntansi. Jadi sesorang yang ingin memiliki motivasi karir yang ringgi dapat meningkatkan minatnya untuk mengikuti Pendidikan Profesi Akuntansi, karena dengan mengikuti itu dapat membantu karirnya di masa depan.

b. Pengaruh Motivasi Mengikuti USAP terhadap Minat Mahasiswa Akuntansi Mengikuti PPAk.

USAP merupakan suatu ujian profesi yang berfungsi sebagai sistem penyaring yang baku bagi mereka yang akan berpraktik sebagai akuntan publik. Departemen Keuangan selaku pembina profesi Akuntan Publik di Indonesia telah mengeluarkan ketentuan yang antara lain mensyaratkan bagi calon Akuntan Publik untuk lulus dari Ujian Sertifikasi Akuntan Publik. Keputusan tersebut telah dituangkan dalam Surat Keputusan Menteri Keuangan Republik Indonesia No. 43/KMK.017/1997 tanggal 27 Januari 1997 jo 470/KMK.017/1999 tanggal 4 Oktober 1999. 


\section{JURNAL NOMINAL / VOLUME II NOMOR II / TAHUN 2013}

Akuntan yang telah dinyatakan lulus untuk semua mata ujian berhak memperoleh sebutan Certified Public Accountant. Sertifikat Akuntan Publik ini merupakan satu persyaratan untuk mendapatkan izin sebagai Akuntan Publik dari Departemen Keuangan. USAP hanya dapat diikuti oleh mereka yang memiliki gelar atau sebutan akuntan yang dibuktikan dengan memiliki Nomor Register Akuntan sesuai dengan peraturan/ketentuan perundang-undangan yang berlaku atau mereka yang telah mengikuti USAP tetapi belum lulus seluruh mata ujian. Namun, nomor Register Akuntan hanya dapat diperoleh lulusan dari PPAk. Jadi untuk peserta USAP diharuskan telah mengikuti PPAk terlebih dahulu.

\section{c. Pengaruh Motivasi Kualitas terhadap Minat Mengikuti PPAk}

Motivasi kualitas adalah dorongan yang timbul dalam diri seseorang untuk memiliki dan meningkatkan kualitas diri dan kemampuannya dalam bidang yang ditekuninya sehingga bisa melaksanakan tugas dengan baik dan benar. Elemen kualitas atau kompetensi adalah hal yang sangat diperhatikan di dalam profesi akuntansi. Bahkan elemen ini dimasukkan dalam Standar Audit. Standar umum auditing yang pertama menyatakan bahwa :

"Audit harus dilaksanakan oleh seorang atau lebih yang memiliki keahlian dan pelatihan teknis yang cukup sebagai auditor".

Dalam melaksanakan audit, auditor harus benar-benar memiliki keahlian dan bertindak sebagai seorang ahli dalam bidang auditing. PPAk dapat meningkatkan kualitas seorang lulusan Sarjana dalam bidang akuntansi yang ingin bekerja di bidang akuntansi. Oleh karena itu jika memiliki motivasi kualitas yang tinggi maka kemungkinan besar minat untuk mengikuti pendidikan profesi akuntansi juga besar.

\section{d. Pengaruh Motivasi Ekonomi terhadap Minat Mahasiswa Akuntansi Mengikuti PPAk}

Penghargaan finansial merupakan salah satu bentuk pengendalian manajemen. Pihak manajemen memberikan reward atau balas jasa untuk memastikan bahwa segenap elemen karyawan bekerja sesuai 
dengan tujuan perusahaan. Motivasi ekonomi dapat diartikan sebagai suatu dorongan yang timbul dalam diri seseorang untuk meningkatkan kemampuan pribadinya dalam rangka mencapai penghargaan finansial dan kemampuan ekonominya.

Seseorang pasti ingin mendapatkan penghargaan finansial yang besar dari pekerjaan yang dilaksanakan. Seseorang tersebut akan meningkatkan kemampuannya agar mendapatkan pekerjaan dengan gaji yang besar. Berkarir di KAP merupakan salah satu karir yang memberikan penghargaan secara finansial dan pengalaman bekerja yang bervariasi. Berkarir di Kantor Akuntan Publik dapat menghasilkan pendapatan yang tinggi dibandingkan pendapatan yang diperoleh dari karir lain. Untuk mendapatkan hal itu dapat ditempuh dengan cara mengikuti Pendidikan Profesi Akuntansi. Dengan mengikuti PPAk kita dapat berpeluang berprofesi menjadi akuntan dengan penghargaan finansial yang cukup besar.

e. Pengaruh Pengetahuan Undang-Undang No.5 tahun 2011 tentang Akuntan Publik terhadap Minat Mahasiswa Akuntansi Mengikuti PPAk.

Pengetahuan adalah hasil tahu yang diperoleh seseorang melalui indra yang dimilikinya. UU No.5 tahun 2011 tentang akuntan publik adalah peraturan yang mengatur tentang akuntan publik. UndangUndang ini antara lain mengatur tentang regulator profesi, asosiasi profesi, perizinan, hak dan kewajiban, tanggung jawab, sangsi, dan lain-lain. Seseorang jika ingin memperoleh segala sesuatu tentang hal yang diinginkan atau diketahui tentu dapat mempengaruhi minat untuk melakukan sesuatu.

Pengetahuan undang - undang tentang akuntan publik disini meliputi aturan-aturan apa saja yang berlaku untuk akuntan publik, persyaratan menjadi akuntan publik bahkan risiko menjadi akuntan publik. Jika seseorang mengetahui syarat tentang akuntan publik, maka kemungkinan orang tersebut memiliki minat untuk menempuh 
pendidikan profesi akuntansi, karena hal itulah yang merupakan syarat untuk menjadi seorang akuntan publik.

f. Pengaruh Motivasi Karir, Motivasi Mengikuti USAP, Motivasi Kualitas, Motivasi Ekonomi dan Pengetahuan Undang-undang No.5 Tahun 2011 tentang Akuntan Publik terhadap Minat Mahasiswa Mengikuti Pendidikan Peofesi Akuntansi.

Motivasi merupakan suatu dorongan yang ada di dalam diri manusia untuk melakukan suatu tindakan yang memiliki tujuan tertentu. Seseorang memerlukan motivasi dalam diri terhadap minat untuk melakukan sesuatu, dalam hal ini minat untuk mengikuti PPAk. Jika seseorang memiliki motivasi karir, motivasi mengikuti USAP, motivasi kualitas, motivasi ekonomi dan lebih mengetahui pengetahuan tentang Akuntan Publik mahasiswa kemungkinan akan berminat untuk mengikuti PPAk. Karena, dengan mengikuti PPAk dapat mewujudkan tujuan dari seseorang yang memiliki motivasi tersebut.

\section{METODE PENELITIAN}

\section{Tempat dan Waktu Penelitian}

Penelitian ini dilaksanakan di Fakultas Ekonomi Universitas Negeri Yogyakarta. Sedangkan waktu penelitian dilaksanakan pada bulan November 2012-Maret 2013.

\section{Jenis penelitian}

Berdasarkan karakteristik masalah, penelitian ini merupakan penelitian kausal komparatif. " Penelitian kausal komparatif merupakan tipe penelitian dengan karakteristik masalah berupa hubungan sebab akibat antara 2 variabel atau lebih" ( Nur Indriantoro dan Bambang Sumpomo 1999:27).

\section{Populasi dan Sampel Penelitian}

Pada penelitian ini populasi terdiri dari mahasiswa akuntansi Universitas Negeri Yogyakarta, baik reguler maupun non reguler yang 
sudah menempuh mata kuliah Pengauditan 1. Dalam penelitian ini populasinya berjumlah:291 Mahasiswa.

Teknik pengambilan sampel pada penelitian ini adalah proportionate stratified sampling, yaitu teknik pengambilan sampel bila populasi memiliki anggota yang tidak homogen dan berstrata secara proporsional. Jumlah sampel dalam penelitian ini adalah 102 mahasiswa.

\section{Teknik Pengumpulan Data}

Teknik pengumpulan data menggunakan angket yang langsung disebarkan kepada mahasiswa akuntansi yang sudah menempuh Pengauditan 1 di Universitas Negeri Yogyakarta (UNY) untuk mengetahui Motivasi Karir, Motivasi Mengikuti USAP, Motivasi Kualitas, Motivasi Ekonomi, Pengetahuan Undang-Undang No.5 tahun 2011 tentang AP dan Minat Mahasiswa Akuntansi Mengikuti PPAk.

\section{Instrumen Penelitian}

a. Kisi-kisi Instrumen penelitian Variabel Motivasi Karir adalah, kesempatan promosi jabatan, kerja sesuai latar belakang pendidikan, kerja dengan baik, pengakuan dari orang lain, meningkatkan kemampuan diri, memperluas akses dunia kerja, mendapatkan pengetahuan. Kisi-kisi Motivasi Mengikuti USAP adalah Dapat Mengikuti Ujian, Menjadi akuntan Publik. Kisi-kisi Motivasi Kualitas adalah Mendapatkan pengetahuan, meningkatkan kemampuan diri. Kisi-kisi Motivasi Ekonomi adalah Penghargaan langsung dan tidak langsung. Kisi- kisi pengetahuan UU no 5 tahun 2011 tentang AP adalah ketentuan umum, bidang jasa, perizinan AP, Syarat AP, Jumlah rekan, Kewajian AP, Penggunaan nama KAP,Kerjasama KAP, Asosiasi Profesi AP, komite Profesi AP, Pembinaan dan Pengawasan, Sangsi. Kisi-kisi Minat Mahasiswa mengikuti PPAk adalah Fungsi PPAk, Manfaat mengikuti PPAk, minat mengikuti PPAk.

\section{b. Pengujian Instrumen}

Uji coba instrumen dilakukan di UNY dengan melibatkan 30 mahasiswa Akuntansi angkatan 2009. 
1) Uji Validitas

Hasil Uji Validitas

\begin{tabular}{|l|c|c|c|}
\hline Variabel & $\begin{array}{l}\text { jumlah } \\
\text { butir awal }\end{array}$ & $\begin{array}{l}\text { Item } \\
\text { gugur }\end{array}$ & $\begin{array}{l}\text { Item } \\
\text { valid }\end{array}$ \\
\hline Motivasi Karir & 10 & 3 & 7 \\
\hline Motivasi Mengikuti USAP & 3 & 0 & 3 \\
\hline Motivasi Kualitas & 10 & 2 & 8 \\
\hline Motivasi Ekonomi & 10 & 2 & 9 \\
\hline $\begin{array}{l}\text { Pengetahuan UU No.5 tahun 2011 } \\
\text { tentang AP }\end{array}$ & 15 & 3 & 12 \\
\hline $\begin{array}{l}\text { Minat mahasiswa Akuntansi } \\
\text { Mengikuti PPAk }\end{array}$ & 5 & 0 & 5 \\
\hline
\end{tabular}

2) Uji reliabilitas

\section{Hasil Uji Reliabilitas}

\begin{tabular}{|l|l|l|}
\hline Variabel & $\begin{array}{l}\text { croanbach } \\
\text { alpha }\end{array}$ & Keterangan \\
\hline Motivasi Karir & 0,810 & Reliabel \\
\hline Motivasi Mengikuti USAP & 0,694 & Reliabel \\
\hline Motivasi Kualitas & 0,762 & Reliabel \\
\hline Motivasi Ekonomi & 0,879 & Reliabel \\
\hline Pengetahuan UU No.5 thn 2011 & 0.874 & Reliabel \\
\hline Minat mengikuti PPAk & 0,798 & Reliabel \\
\hline
\end{tabular}

\section{Teknik Analisis data}

\section{a. Uji Asumsi Klasik}

1) Uji Normalitas

Uji normalitas bertujuan untuk menguji apakah dalam model regresi, variabel tergantung dan variabel bebas keduanya mempunyai distribusi normal atau tidak. Metode yang dipakai untuk mengetahui kenormalan model regresi adalah One Sample Kolmogorov-Smirnov Test. Oleh karena penelitian ini menggunakan taraf signifikansi 5\%, maka jika nilai signifikansi (dapat dilihat pada Asymp. Sig. pada output SPSS) dari nilai 
Kolmogorov Smirnov > 5\%, data yang digunakan berdistribusi normal (Imam Ghozali, 2011: 150).

2) Multikolinieritas

Uji multikolinieritas bertujuan untuk mengetahui apakah dalam model regresi ditemukan adanya korelasi antar variabel bebas. Model regresi yang baik seharusnya tidak terjadi korelasi antar variabel bebas. Untuk mengetahui ada atau tidaknya multikolinieritas maka dapat dilihat dari nilai Varians Inflation Factor (VIF) dan tolerance $(\alpha)$. Batas dari nilai tolerance value adalah 0,01 dan VIF adalah 10. Apabila tolerance value dibawah 0,01 atau nilai VIF di atas 10 maka terjadi multikolinieritas ( Imam Ghozali, 2011:106).

3) Uji Linieritas

Uji linieritas digunakan untuk mengetahui hubungan antara variabel bebas dan variabel terikat bersifat linier atau tidak. Uji linieritas merupakan kuci yang digunakan untuk masuk ke model regresi linear. Apabila kunci tersebut tidak sesuai, artinya dari hasil uji linieritas menyatakan bahwa garis regresi tidak linier, mka regresi linier tidak dapat digunakan untuk menganalisis data (Sudarmanto, 2005:125). Pengujian ini menggunakan uji lagrange multiplier. Estimasi dengan uji ini bertujuan untuk mendapatkan nilai $\mathrm{C}^{2}$ atau ( $\mathrm{n} \times \mathrm{R}^{2}$ ). Untuk pengambilan keputusannya digunakan kriteria berikut :

a. Jika $\mathrm{C}^{2}$ hitung $>\mathrm{C}^{2}$ tabel, maka model regresi tidak linier

b. Jika $\mathrm{C}^{2}$ hitung $<\mathrm{C}^{2}$ tabel, maka model regresi linier (Imam Ghozali,2011:169).

4) Heteroskedastisitas

Uji heteroskedastisitas bertujuan untuk mengetahui apakah ada model regresi ini terjadi ketidaksamaan varian dari residu satu pengamatan ke pengamatan lain. Jika varian dari residu pengamatan ke pengamatan lain berbeda berarti ada gejala heteroskedastisitas dalam model regresi tersebut. Model regresi 
yang baik tidak terjadi adanya heteroskedastisitas. Pada penelitian ini, cara yang digunakan untuk mendeteksi heteroskedasatisitas adalah menggunakan Uji Park. Uji Park dilakukan dengan meregresi logaritma dari kuadrat residual hasil regresi awal dari variabel-variabel independennya. Apabila nilai $t_{\text {hitung }}<t_{\text {tabel }}$ atau signifikansi $>0,05$ berarti menunjukkan adanya homosdekastisitas atau tidak menunjukkan gejala heteroskedastisitas (Imam Ghozali, 2011: 142).

\section{b. Uji Hipotesis}

1) Uji Regresi Sederhana

Analisis regresi sederhana ini digunakan untuk menguji hipotesis 1-5. Sugiyono (2003) rumus yang digunakan dalam analisis regresi sederhana adalah sebagai berikut :

$\mathrm{Y}=\mathrm{a}+\mathrm{bx}$

2) Analisis regresi Ganda

Analisis regresi digunakan untuk menguji hipotesis keenam, memprediksi pengaruh lebih dari satu variabel bebas terhadap satu variabel bergantung, baik secara parsial maupun simultan.

\section{HASIL PENELITIAN DAN PEMBAHASAN}

\section{Hasil Analisi Data}

a. Variabel Motivasi Karir

Data Motivasi Karir diperoleh dari angket dengan jumlah pertanyaan 7 butir dan responden sebanyak 102 mahasiswa. Angket tersebut disusun menggunakan skala likert yang terdiri dari 4 alternatif jawaban, sehingga dihasilkan skor tertinggi ideal sebesar 28 dan skor terendah ideal sebesar 7. Hasil analisis data menunjukkan bahwa Mean sebesar 22,28, Median sebesar 22, modus sebesar 22 dan standar deviasi sebesar 2,622.

b. Variabel Motivasi Mengikuti USAP

Data Motivasi Mengikuti USAP diperoleh dari angket dengan jumlah pertanyaan 3 butir dan responden sebanyak 102 mahasiswa. Angket 
tersebut disusun menggunakan skala likert yang terdiri dari 4 alternatif jawaban, sehingga dihasilkan skor tertinggi ideal sebesar 12 dan skor terendah ideal sebesar 3. Berdasarkan data penelitian yang diolah, variabel Motivasi Mengikuti USAP memiliki skor tertinggi sebesar 12, skor terendah sebesar 4, Mean sebesar 9,12, median sebesar 9, modus sebesar 9 dan standar deviasi sebesar 1,409.

c. Variabel Motivasi Kualitas

Data Motivasi Kualitas diperoleh dari angket dengan jumlah pertanyaan 8 butir dan responden sebanyak 102 mahasiswa. Angket tersebut disusun menggunakan skala likert yang terdiri dari 4 alternatif jawaban, sehingga dihasilkan skor tertinggi ideal sebesar 32 dan skor terendah ideal sebesar 8. Berdasarkan data penelitian yang diolah, variabel Motivasi Kualitas memiliki skor tertinggi sebesar 32, skor terendah sebesar 8, Mean sebesar 25,1667, median sebesar 24, modus sebesar 24 dan standar deviasi sebesar 3,464

d. Variabel Motivasi Ekonomi

Data Motivasi Ekonomi diperoleh dari angket dengan jumlah pertanyaan 9 butir dan responden sebanyak 102 mahasiswa. Angket tersebut disusun menggunakan skala likert yang terdiri dari 4 alternatif jawaban, sehingga dihasilkan skor tertinggi ideal sebesar 36 dan skor terendah ideal sebesar 9. Berdasarkan data penelitian yang diolah, variabel Motivasi Ekonomi memiliki skor tertinggi sebesar 36, skor terendah sebesar 14, Mean sebesar 24,55, Median sebesar 25, modus sebesar 27 dan standar deviasi sebesar 4,311

e. Variabel Pengetahuan UU No.5 Tahun 2011 tentang Akuntan Publik Data Pengetahuan Undang-Undang No.5 Tahun 2011 tentang Akuntan Publik diperoleh dari angket dengan jumlah pertanyaan 12 butir dan responden sebanyak 102 mahasiswa. Angket tersebut disusun menggunakan skala likert yang terdiri dari 4 alternatif jawaban, sehingga dihasilkan skor tertinggi ideal sebesar 48 dan skor terendah ideal sebesar 12. Berdasarkan data penelitian yang diolah, variabel Pengetahuan Undang-Undang No.5 tahun 2011 tentang Akuntan 
Publik memiliki skor tertinggi sebesar 48, skor terendah sebesar 20, Mean sebesar 37,39, Median sebesar 15, Modus sebesar 15 dan standar deviasi sebesar 4,034.

f. Variabel Minat Mahasiswa Akuntansi Mengikuti PPAk

Data Minat Mahasiswa Akuntansi Mengikuti PPAk diperoleh dari angket dengan jumlah pertanyaan 5 butir dan responden sebanyak 102 mahasiswa. Angket tersebut disusun menggunakan skala likert yang terdiri dari 4 alternatif jawaban, sehingga dihasilkan skor tertinggi ideal sebesar 20 dan skor terendah ideal sebesar 5. Berdasarkan data penelitian yang diolah menggunakan bantuan computer program SPSS, variabel Minat Mahasiswa Akuntansi Mengikuti PPAk memiliki skor tertinggi sebesar 20, skor terendah sebesar 6, Mean sebesar 16,03, median sebesar 15 , modus sebesar15 dan standar deviasi sebesar 2,22

\section{Hasil Uji Asumsi Klasik}

a. Uji normalitas dilakukan untuk mengetahui apakah sebaran data yang akan dianalisis berdistribusi normal atau tidak. Hasil uji normalitas diperoleh dengan menggunakan uji Kolmogrov smirnov yang dihitung dengan Program statistik SPSS 16. Berikut ini adalah hasil uji normalitas

\section{Tabel Ringkasan hasil uji Normalitas.}

\begin{tabular}{|c|c|c|c|}
\hline \multicolumn{1}{|c|}{ Variabel } & Asimtotic sig & Harga $\alpha$ & keterangan \\
\hline $\begin{array}{l}\text { Unstandardized } \\
\text { residual }\end{array}$ & 0,247 & 0,05 & normal \\
\hline
\end{tabular}

b. Uji multikolinieritas

Uji Multikolinieritas bertujuan untuk mengetahui ada tidaknya multikolinieriras antara variabel bebas (independen) sebagai syarat digunakannya regresi ganda dalam menguji hipotesis.

Tabel Ringkasan hasil uji Multikolinieritas

\begin{tabular}{|l|c|c|}
\hline \multicolumn{1}{|c|}{ Nama variabel } & Tolerance & VIF \\
\hline Motivasi karir & 0,458 & 2,185 \\
\hline Motivasi mengikuti USAP & 0,559 & 1,788 \\
\hline Motivasi Kualitas & 0,464 & 2,153 \\
\hline Motivasi ekonomi & 0,739 & 1,353 \\
\hline Pengetahuan UU & 0,931 & 1,074 \\
\hline
\end{tabular}


c. Uji linieritas digunakan untuk mengetahui hubungan antara variabel bebas dan variabel terikat bersifat linier atau tidak. Uji linieritas merupakan kuci yang digunakan untuk masuk ke model regresi linear. Apabila kunci tersebut tidak sesuai, artinya dari hasil uji linieritas menyatakan bahwa garis regresi tidak linier, maka regresi linier tidak dapat digunakan untuk menganalisis data.

\section{Tabel Hasil Uji Linieritas}

Model Summary b

\begin{tabular}{|l|r|r|r|r|}
\hline Model & $\mathrm{R}$ & R Square & Adjusted R Square & \multicolumn{1}{c|}{$\begin{array}{c}\text { Std. Error of the } \\
\text { Estimate }\end{array}$} \\
\hline 1 & $.583^{\mathrm{a}}$ & .340 & .306 & 1.85151 \\
\hline
\end{tabular}

a. Predictors: (Constant), pengetahuan uu, motivasi ekonomi, motivasi usap, motivasi

kualitas, motivasi karir

b. Dependent Variable: minat ppak

Sumber: Lampiran 5 hlm 140

Berdasarkan hasil uji Lagrange Multiplier diperoleh nilai $\mathrm{R}^{2}$ sebesar 0,306, maka besarnya $\mathrm{C}^{2}$ hitung $=\mathrm{n} \times \mathrm{R}^{2}=102 \times 0,306=31,212$. Dengan demikian $C^{2}$ hitung $(31,212)<C^{2}$ tabel $(125,487)$ sehingga dapat disimpulkan model regresi tersebut linear.

d. Uji heteroskedastisitas

Uji Heteroskedastisitas bertujuan untuk menguji apakah dalam model regresi terjadi ketidaksamaan variance dari residual satu pengamatan ke pengamatan yang lain. Jika variance dari residual satu pengamatan ke pengamatan lain tetap maka disebut homokedastisitas dan jika berbeda di sebut heteroskedastisitas.

Pada penelitian ini digunakan uji Park untuk mendeteksi ada tidaknya heteroskedastisitas. Uji Park dilakukan dengan meregresi logaritma dari kuadrat residual hasil regresi awal dari variabel-variabel independennya. Kriteria pengujiannya adalah dengan melihat nilai koefisien regresi pada persamaan. Apabila nilai $t_{\text {hitung }}<t_{\text {tabel }}$ atau signifikansi $>0,05$ berarti menunjukkan adanya homosdekastisitas atau tidak menunjukkan gejala heteroskedastisitas (Imam Ghozali, 2011: 142). Hasil uji Heteroskedastisitas diperoleh dengan menggunakan bantuan program statistik spss 16 . 
Tabel Ringkasan Hasil Uji Heteroskedastisitas.

\begin{tabular}{|l|c|c|}
\hline \multicolumn{1}{|c|}{ Nama variabel } & t $_{\text {hitung }}$ & \multicolumn{1}{l|}{ Sig } \\
\hline Motivasi karir & $-0,244$ & 0,808 \\
\hline Motivasi mengikuti USAP & $-0,075$ & 0,941 \\
\hline Motivasi Kualitas & $-0,231$ & 0,817 \\
\hline Motivasi ekonomi & 0,038 & 0,701 \\
\hline Pengetahuan UU & 0,647 & 0,519 \\
\hline
\end{tabular}

\section{Hasil Uji Hipotesis Penelitian}

a. Pengujian Hipotesis Pertama

Pengujian Hipotesis Pertama menggunakan analisis regresi sederhana.

Tabel rangkuman uji hipotesis.

\begin{tabular}{|l|c|c|c|c|c|c|l|}
\hline \multirow{2}{*}{ Variabel } & \multirow{2}{*}{$\mathrm{r}$} & \multirow{2}{*}{$\mathrm{r}^{2}$} & \multicolumn{2}{|c|}{ Nilai $\mathrm{i}$} & \multirow{2}{*}{ Sig } & \multicolumn{2}{|c|}{ Nilai B } \\
\cline { 4 - 5 } & & & Hitung & Tabel & & Constant & $\mathrm{X} 1$ \\
\hline $\mathrm{X} 1$ ke Y & 0,468 & 0,219 & 5,289 & 1,984 & 0,00 & 7,201 & 0,396 \\
\hline
\end{tabular}

1) Persamaan garis regresi

$Y=7,201+0,396 X_{1}$, Persamaan tersebut menunjukkan bahwa koefisien $\mathrm{X}_{1}$ sebesar 0,396 yang berarti apabila nilai Motivasi Karir meningkat 1 poin maka nilai Minat Mahasiswa Akuntansi Mengikuti PPAk akan naik sebesar 0,396 poin.

2) Nilai $\mathbf{r}^{2}$

0,219 berarti $21,19 \%$ perubahan pada variabel Minat Mahasiswa Akuntansi Mengikuti PPAk dapat diterangkan oleh variabel Motivasi Karir, sedangkan 78,10\% dijelaskan oleh variabel lain yang tidak dianalisis.

\section{3) Uji signifikansi t}

Hipotesis yang di uji adalah Terdapat pengaruh positif antara Motivasi Karir terhadap Minat Mahasiswa Akuntansi Mengikuti Pendidikan Profesi Akuntansi. Berdasarkan hasil uji $\mathrm{t}$ diperoleh nilai $\mathrm{t}_{\text {hitung }}$ sebesar 5,289> $\mathrm{t}_{\text {tabel }}$ sebesar 1,984 pada taraf signifikansi 5\%, yang berarti pengaruh Motivasi Karir terhadap Minat Mahasiswa Akuntansi Mengikuti PPAk adalah signifikan. 
b. Pengujian Hipotesis kedua

Pengujian hipotesis kedua ini menggunakan regresi sederhana.

Tabel Rangkuman hasil analisis regresi sederhana X2

\begin{tabular}{|l|c|c|c|c|c|c|l|}
\hline \multirow{2}{*}{ Variabel } & \multirow{2}{*}{$\mathrm{R}$} & \multirow{2}{*}{$\mathrm{r}^{2}$} & \multicolumn{2}{|c|}{ Nilai t } & \multirow{2}{*}{ Sig } & \multicolumn{2}{|c|}{ Nilai B } \\
\cline { 4 - 5 } & & & Hitung & Tabel & & Constant & $\mathrm{X} 2$ \\
\hline $\mathrm{X} 2$ ke Y & 0,397 & 0,158 & 5,289 & 1,984 & 0,00 & 10,318 & 0,626 \\
\hline
\end{tabular}

\section{1) Persamaan garis regresi}

$Y=10,318+0,626 X_{2}$, Persamaan tersebut menunjukkan bahwa nilai Motivasi Mengikuti USAP meningkat 1 poin maka nilai Minat Mahasiswa Akuntansi Mengikuti PPAk akan naik sebesar 0,626 poin.

2) Nilai $\mathbf{r}^{2}$

0,158 berarti 15,8\% perubahan pada variabel Minat Mahasiswa Akuntansi Mengikuti PPAk dapat diterangkan oleh variabel Motivasi Mengikuti USAP, sedangkan 84,2\% dijelaskan oleh variabel lain yang tidak dianalisis.

3) Nilai signifikansi t

Hipotesis yang di uji adalah Terdapat pengaruh positif antara Motivasi Mengikuti USAP terhadap Minat Mahasiswa Akuntansi Mengikuti Pendidikan Profesi Akuntansi. Berdasarkan hasil uji t diperoleh nilai $t_{\text {hitung }}$ sebesar 4,328> nilai $\mathrm{t}_{\text {tabel }}$ sebesar 1,984 pada taraf signifikansi 5\%, Hal ini berarti bahwa ada pengaruh signifikan antara Motivasi Mengikuti USAP terhadap Minat Mahasiswa Akuntansi Mengikuti PPAk.

c. Pengujian Hipotesis ketiga

Pengujian hipotesis ketigaa ini menggunakan regresi sederhana.

Tabel Rangkuman hasil analisis regresi sederhana X3

\begin{tabular}{|l|c|c|r|r|r|r|l|}
\hline \multirow{2}{*}{ Variabel } & \multirow{2}{*}{$r$} & \multirow{2}{*}{$r^{2}$} & \multicolumn{2}{|c|}{ Nilai t } & \multicolumn{2}{|c|}{ Sig } & \multicolumn{2}{|c|}{ Nilai B } \\
\cline { 4 - 5 } & & & Hitung & Tabel & & Constant & X3 \\
\hline X3 ke Y & 0,467 & 0,218 & 5,287 & 1,984 & 0,00 & 8,483 & 0,300 \\
\hline
\end{tabular}




\section{1) Persamaan Garis Regresi}

$Y=8.483+0,300 X_{3}$, Persamaan tersebut berarti apabila nilai Motivasi Kualitas meningkat 1 poin maka nilai Minat Mahasiswa Akuntansi Mengikuti PPAk akan naik sebesar 0,300 poin.

2) Nilai $\mathbf{r}^{2}$

Nilai 0,218 berarti $21,8 \%$ perubahan pada variabel Minat Mahasiswa Akuntansi Mengikuti PPAk dapat diterangkan oleh variabel Motivasi Kualitas, sedangkan 78,2\% dijelaskan oleh variabel lain yang tidak dianalisis.

\section{3) Uji signifikansi $t$}

Berdasarkan hasil uji t diperoleh nilai thitung sebesar 5,287> nilai $\mathrm{t}_{\text {tabel }}$ sebesar 1,984 pada taraf signifikansi 5\%, Hal ini berarti bahwa ada pengaruh signifikan antara Motivasi Kualitas terhadap Minat Mahasiswa Akuntansi Mengikuti PPAk.

d. Pengujian hipotesis keempat

Pengujian hipotesis keempat ini menggunakan regresi sederhana.

Tabel Rangkuman hasil analisis regresi sederhana

\begin{tabular}{|l|c|c|r|r|r|r|l|}
\hline \multirow{2}{*}{ Variabel } & \multirow{2}{*}{$\mathrm{r}$} & \multirow{2}{*}{$\mathrm{r}^{2}$} & \multicolumn{2}{|c|}{ Nilai $\mathrm{i}$} & \multirow{2}{*}{ Sig } & \multicolumn{2}{|c|}{ Nilai B } \\
\cline { 4 - 5 } & & & Hitung & Tabel & & Constant & $\mathrm{X} 4$ \\
\hline X4 ke Y & 0,414 & 0,171 & 4,544 & 1,984 & 0,00 & 10,794 & 0,213 \\
\hline
\end{tabular}

1) Persamaan garis regresi

$Y=10,794+0,213 X_{3}$, Persamaan tersebut berarti apabila nilai Motivasi Ekonomi meningkat 1 poin maka nilai Minat Mahasiswa Akuntansi Mengikuti PPAk akan naik sebesar 0,213 poin.

2) Nilai $\mathbf{r}^{2}$

Nilai 0,171 tersebut berarti $17,1 \%$ perubahan pada variabel Minat Mahasiswa Akuntansi Mengikuti PPAk dapat diterangkan oleh variabel Motivasi Ekonomi, sedangkan 82,9\% dijelaskan oleh variabel lain yang tidak dianalisis.

\section{3) Uji signifikansi t}

Berdasarkan hasil uji t diperoleh nilai $t_{\text {hitung }}$ sebesar 4,544> $\mathrm{t}_{\text {tabel }}$ sebesar 1,984 pada taraf signifikansi 5\%, Hal ini berarti 
bahwa ada pengaruh signifikan antara Motivasi Ekonomi terhadap Minat Mahasiswa Akuntansi Mengikuti PPAk.

e. Pengujian hipotesis kelima

Pengujian hipotesis kelima ini menggunakan regresi sederhana.

Tabel rangkuman hasil analisis regresi sederhana X5

\begin{tabular}{|l|c|c|c|c|c|c|l|}
\hline \multirow{2}{*}{ Variabel } & \multirow{2}{*}{$\mathrm{r}$} & \multirow{2}{*}{$\mathrm{r}^{2}$} & \multicolumn{2}{|c|}{ Nilai $\mathrm{i}$} & \multirow{2}{*}{ Sig } & \multicolumn{2}{|c|}{ Nilai B } \\
\cline { 4 - 5 } & & & Hitung & Tabel & & Constant & X5 \\
\hline X5 ke Y & 0,235 & 0,055 & 2,417 & 1,984 & 0,17 & 11,190 & 0,129 \\
\hline
\end{tabular}

1) Persamaan garis regresi

$\mathrm{Y}=11,190+0,129 \mathrm{X}_{5}$, Persamaan tersebut berarti apabila nilai PengetahuanUndang-Undang No.5 Tahun 2011 tentang Akuntan Publik meningkat 1 poin maka nilai Minat Mahasiswa Akuntansi Mengikuti PPAk akan naik sebesar 0,129 poin.

2) Nilai $\mathbf{r}^{2}$

Nilai 0,055 tersebut berarti $5,5 \%$ perubahan pada variabel Minat Mahasiswa Akuntansi Mengikuti PPAk dapat diterangkan oleh variabel Pengetahuan Undang-Undang No.5 Tahun 2011 tentang Akuntan Publik, sedangkan 94,5\% dijelaskan oleh variabel lain yang tidak dianalisis.

\section{3) Uji signifikansi t}

Berdasarkan hasil uji $t$ diperoleh nilai $t_{\text {hitung }}$ sebesar 2,417> $t_{\text {tabel }}$ sebesar 1,984 pada taraf signifikansi 5\%, Hal ini berarti bahwa ada pengaruh signifikan antara Pengetahuan Undang-Undang No.5 Tahun 2011 tentang Akuntan Publik terhadap Minat Mahasiswa Akuntansi Mengikuti PPAk.

f. Pengujian hipotesis keenam

$Y=1,599+0,166 X_{1}+0,103 X_{2}+0,095 X_{3}+0,132 X_{4}+0,111 X_{5}$

Berdasarkan analisis data dengan menggunakan program SPSS, menunjukkan $\mathrm{R}^{2}$ sebesar 0,306 . Nilai tersebut berarti $30,6 \%$ perubahan pada variabel Minat Mahasiswa Akuntansi Mengikuti Pendidikan Profesi Akuntansi dapat diterangkan oleh Motivasi Karir, Motivasi Mengikuti USAP, Motivasi Kualitas, Motivasi Ekonomi dan Pengetahuan Undang- 
undang No.5 tahun 2011 tentang Akuntan Publik, sedangkan 69,4\% dijelaskan oleh variabel lain yang tidak dianalisis.

Berdasarkan uji $\mathrm{F}$ diperoleh nilai $\mathrm{F}_{\text {hitung }}$ sebesar 9,907, sedangkan nilai $F_{\text {tabel }}$ sebesar 2,309 pada taraf signifikansi 5\%. Nilai $F_{\text {hitung }}>F_{\text {tabel }}$ sehingga hipotesis ke enam diterima. Hal ini berarti Motivasi Karir, Motivasi Mengikuti USAP, Motivasi Kualitas, Motivasi Ekonomi dan Pengetahuan Undang-Undang No.5 tahun 2011 Tentang Akuntan Publik secara bersama-sama berpengaruh signifikan terhadap Minat Mahasiswa Akuntansi Mengikuti Pendidikan Profesi Akuntansi.

\section{Pembahasan}

a. Hasil penelitian mengenai pengaruh Motivasi Karir terhadap Minat Mahasiswa Akuntansi Mengikuti Pendidikan Profesi Akuntansi berpengaruh positif dan signifikan. Hal ini dibuktikan dengan nilai koefisien determinasi $r^{2}$ sebesar 0,219, artinya variabel Motivasi Karir memberikan kontribusi sebesar 21,9\% dalam menjelaskan variabel Minat Mahasiswa Akuntansi mengikuti PPAk. Selain itu pengaruh yang signifikan ditunjukkan dengan $t_{\text {hitung }}>t_{\text {tabel }}(5,289>1,984)$ dan probabilitas $\mathrm{t}_{\text {hitung }}<$ probabilitas $5 \% \quad(0,00<0,05)$.Berdasarkan hasil tersebut maka hipotesis pertama diterima.

b. Hasil penelitian mengenai pengaruh Motivasi Mengikuti USAP terhadap Minat Mahasiswa Akuntansi Mengikuti Pendidikan Profesi Akuntansi berpengaruh positif dan signifikan. Hal ini dibuktikan dengan nilai koefisien determinasi $r^{2}$ sebesar 0,158 , artinya variabel Motivasi Mengikuti USAP memberikan kontribusi sebesar 15,8\% dalam menjelaskan variabel Minat Mahasiswa Akuntansi Mengikuti PPAk. Selain itu pengaruh yang signifikan ditunjukkan dengan $t_{\text {hitung }}>$ $\mathrm{t}_{\text {tabel }} \quad(4,328>1,954)$ dan probabilitas $\mathrm{t}_{\text {hitung }}<$ probabilitas $5 \%$ $(0,00<0,05)$. Berdasarkan hasil tersebut maka, hipotesis kedua diterima.

c. Hasil penelitian mengenai pengaruh Motivasi Kualitas terhadap Minat Mahasiswa Akuntansi Mengikuti Pendidikan Profesi Akuntansi berpengaruh positif dan signifikan. Hal ini dibuktikan dengan nilai koefisien determinasi $r^{2}$ sebesar 0,218, artinya variabel Motivasi 
Kualitas memberikan kontribusi sebesar 21,8 dalam menjelaskan variabel Minat Mahasiswa Akuntansi Mengikuti PPAk. Selain itu pengaruh yang signifikan ditunjukkan dengan $t_{\text {hitung }}>t_{\text {tabel }}$ $(5,287>1,954)$ dan probabilitas $t_{\text {hitung }}<$ probabilitas $5 \%(0,00<0,05)$.

d. Hasil penelitian mengenai pengaruh Motivasi Ekonomi terhadap Minat Mahasiswa Akuntansi Mengikuti Pendidikan Profesi Akuntansi berpengaruh positif dan signifikan. Hal ini dibuktikan dengan nilai koefisien determinasi parsial $r^{2}$ sebesar 0,171 artinya variabel Motivasi Ekonomi memberikan kontribusi sebesar 17,1\% dalam menjelaskan variabel Minat Mahasiswa Akuntansi Mengikuti PPAk. Selain itu pengaruh yang signifikan ditunjukkan dengan $t_{\text {hitung }}>t_{\text {tabel }}$ $(4.544>1,954)$ dan probabilitas $t_{\text {hitung }}<$ probabilitas $5 \% \quad(0,00<0,05)$. Berdasarkan hasil tersebut maka, hipotesis keempat diterima.

e. Hasil penelitian mengenai pengaruh Pengetahuan Undang-Undang No.5 tahun 2011 tentang Akuntan Publik terhadap Minat Mahasiswa Akuntansi Mengikuti Pendidikan Profesi Akuntansi berpengaruh positif dan signifikan. Hal ini dibuktikan dengan nilai koefisien determinasi $\mathrm{r}^{2}$ sebesar 0,055, artinya variabel Pengetahuan UndangUndang No.5 tahun 2011 tentang Akuntan Publik memberikan kontribusi 5,5\% dalam menjelaskan variabel Minat Mahasiswa Akuntansi Mengikuti PPAk. Selain itu pengaruh yang signifikan ditunjukkan dengan $t_{\text {hitung }}>t_{\text {tabel }}(2,417>1,954)$ dan probabilitas $\mathrm{t}_{\text {hitung }}<$ probabilitas $5 \%(0,017<0,05)$. Berdasarkan hasil tersebut maka, hipotesis kelima diterima

f. Hasil penelitian mengenai pengaruh Motivasi Karir, Motivasi Mengikuti USAP, Motivasi Kualitas, Motivasi Ekonomi dan Pengetahuan Undang-undang No.5 tahun 2011 tentang Akuntan Publik berpengaruh positif dan signifikan. Hal ini dibuktikan dengan nilai koefisien determinasi sebesar 0,306, yang berarti naik turunnya nilai Minat Mahasiswa Akuntansi Mengikuti PPAk dipengaruhi oleh variabel Motivasi Karir, Motivasi Mengikuti USAP, Motivasi Kualitas, 
Motivasi Ekonomi, Pengetahuan uu no 5 tahun 2011 tentang Akuntan Publik sebesar $30,6 \%$.

\section{E. PENUTUP}

1. Kesimpulan

a. Motivasi Karir berpengaruh positif dan signifikan terhadap Minat Mahasiswa Akuntansi Mengikuti PPAk. Hal ini dibuktikan dengan nilai thitung sebesar 5,289 > nilai ttabel sebesar 1,984 koefisien regresi $\mathrm{r}_{\mathrm{x} 1 \mathrm{y}}$ sebesar 0,468 dan koefisien determinasi sebesar 0,219.

b. Motivasi Mengikuti USAP berpengaruh positif dan signifikan terhadap Minat Mahasiswa Akuntansi Mengikuti PPAk. Hal ini dibuktikan dengan nilai $\mathrm{t}$ hitung 4,528 > nilai t tabel 1,984, koefisien regresi $r_{x 1 y}$ sebesar 0,397 dan koefisien determinasi sebesar 0,158 .

c. Motivasi Kualitas berpengaruh positif dan signifikan terhadap Minat Mahasiswa Akuntansi Mengikuti PPAk. Hal ini dibuktikan dengan $\mathrm{t}$ hitung sebesar 5,287> nilai t tabel sebesar 1,984 koefisien regresi $r_{x 1 y}$ sebesar 0,467 dan koefisien determinasi sebesar 0,218 .

d. Motivasi Ekonomi berpengaruh positif dan signifikan terhadap Minat Mahasiswa Akuntansi Mengikuti PPAk. Hal ini dibuktikan dengan nilai $\mathrm{t}$ hitung sebesar 4,544 >nilai t tabel sebesar 1,984 koefisien regresi $r_{x 1 y}$ sebesar 0,414 dan koefisien determinasi sebesar 0,171 .

e. Pengetahuan Undang-Undang No.5 tahun 2011 tentang Akuntan Publik berpengaruh positif dan signifikan terhadap Minat Mahasiswa Akuntansi Mengikuti PPAk. Hal ini dibuktikan dengan hasil analisis uji t menunjukkan bahwa nilai t hitung sebesar 2,417 $>$ nilai $t$ tabel sebesar 1,984 koefisien regresi $r_{x 1 y}$ sebesar 0,235 dan koefisien determinasi sebesar 0,055.

f. Motivasi Karir, Motivasi Mengikuti USAP, Motivasi Kualitas, Motivasi Ekonomi, Pengetahuan Undang-Undang No.5 tahun 2011 
tentang Akuntan Publik secara bersama-sama berpengaruh positif terhadap Minat Mahasiswa Akuntansi Mengikuti Pendidikan Profesi Akuntansi. Hal ini dibuktikan dengan hasil analisis uji $\mathrm{F}$ menunjukkan $\mathrm{F}$ hitung sebesar 9,907 dan probabilitasnya 0,00 sedangkan harga $\mathrm{F}$ tabel sebesar 2,309 pada probabilitas 0,05 . Nilai $\mathrm{F}$ hitung $>\mathrm{F}$ tabel. Harga probabilitas $\mathrm{F}$ hitung sebesar $0,00<$ 0,05. Angka koefisien determinasi sebesar 0,306 menunjukkan bahwa minat mahasiswa akuntansi mengikuti PPAk dapat dijelaskan oleh variabel Motivasi Karir, Motivasi Mengikuti USAP, Motivasi Kualitas, Motivasi Ekonomi dan Pengetahuan Undang-Undang tentang Akuntan Publik sebesar 30,6\%, sedangkan sisanya $69,4 \%$ berasal dari variabel lain.

2. Keterbatasan Penelitian

a. Penelitian ini menggunakan angket dalam pengumpulan data, maka memungkinkan data yang diperoleh bias, karena Ketidakseriusan responden dalam mengisi angket, Kesalahan interpretasi oleh responden mengenai maksud pertanyaan yang sesungguhnya, sehingga variabel tidak terukur sempurna.

b. Penelitian ini hanya mengambil sampel mahasiswa S1 Akuntansi Fakultas Ekonomi Universitas Negeri Yogyakarta sehingga hasil penelitian tidak bisa digeneralisasikan.

c. Pertanyaan angket pada Pengetahaun Undang-Undang No.5 tahun 2011 tentang Akuntan Publik belum bisa merefleksikan semua pengetahuan yang terkandung dalam Undang-Undang.

3. Saran

Pada penelitian selanjutnya peneliti menyarankan untuk memperluas sampel yang digunakan agar hasilnya dapat digeneralisasikan, Instrumen penelitian dikembangkan lagi sehingga dapat lebih mengukur variabel tersebut. Variabel yang diteliti pada penelitian ini hanya menyumbang 30,06\% dalam mempengaruhi minat mahasiswa untuk mengikuti Pendidikan Profesi Akuntansi, sehingga 
diharapkan peneliti selanjutnya, dapat menggunakan variabel lain untuk penelitiannya.

\section{F. DAFTAR PUSTAKA}

Al Haryono Jusup. (2001). Auditing. Yogyakarta : BPFE

Benny, Ellya dan Yuskar. (2006). Pengaruh Motivasi terhadap Minat Mahasiswa Akuntansi untuk Mengikuti Pendidikan Profesi Akuntansi (PPAk). Prosiding Simposium Nasional Akuntansi IX.

Departemen Keuangan. (2011). Undang-undang Akuntan Publik”. Diambil dari:

http://www.ppajp.depkeu.go.id/remository/downloads/uuap5-2011bt.pdf, pada tanggal 18 oktober 2012.

Depdiknas. Kamus Besar Bahasa Indonesia. Jakarta: Balai Pustaka.

Djaali. (2007). Psikologi pendidikan. Jakarta: Bumi Aksara.

IAI. (2012) . Keluhkkan minimnya jumlah akuntan publik" Diambil dari: http://www.hukumonline.com/berita/baca/lt4e9eb67f7300c/iai-

keluhkan-minimnya-jumlah-akuntan-publik-an, pada tanggal 12 November 2012.

Imam Ghozali. (2009). Aplikasi Analisis Multivariate dengan Program SPSS.

Semarang: Badan Penerbit Universitaas Diponegoro. . (2011). Aplikasi Analisis Multivariate dengan Program IBM

SPSS 19. Semarang: Badan Penerbit Fakultas Ekonomi Universitas Diponegoro.

Lani Afriyantini. (2008). Pengaruh Pengetahuan Tentang Profesi Auditor dan Persepsi Mahasiswa tentang Profesi Auditor Terhadap Minat Menjadi Auditor Pada Mahasiswa Akuntansi FISE UNY. Skripsi, Universitas Negeri Yogyakarta.

Malayu SP Hasibuan. (2003). Organisasi dan Motivasi Dasar Peningkatan Produktivitas. Jakarta: Bumi Aksara.

Muhammad Iqbal. (2011). Pengaruh Motivasi terhadap Minat Mahasiswa Akuntansi untuk Mengikuti Pendidikan PPAk: Studi Kasus pada 


\section{JURNAL NOMINAL / VOLUME II NOMOR II / TAHUN 2013}

Mahasiswa Akuntansi Universitas Diponegoro Semarang. Skripsi.

Universitas Diponegoro Semarang.

Muhibbin Syah. (2004). Psikologi Pendidikan Dengan Pendekatan Baru.

Bandung : PT Rosdakarya.

Nana Syaodih Sukmadinata. (2003). Landasan Psikologi Proses Pendidikan.

Bandung: PT Remaja Rosdakarya.

Ngalim Purwanto. (2002). Psikologi Pendidikan. Bandung: PT Remaja Rosdakarya.

Notoatmodjo. (2007). Pengertian Pengetahuan. Diamil dari: http://id.wikipedia.org/wiki/pengetahuan, pada tanggal 8 oktober 2012.

Nur Indriantoro dan Bambang Sumpomo. (1999). Metode Penelitian Bisnis. Yogyakarta : BPFE.

Riani Nurainah Lisnasari, Fitriany. (2008). Faktor yang Mempengaruhi Minat

Mahasiswa Akuntansi untuk Mengikuti Pendidikan Profesi Akuntansi.

Saifudin Azwar. (2000). Reliabilitas dan Validitas.Yogyakarta: Pustaka Pelajar Offset.

Samiaji. (2004). Pengaruh Motivasi Terhadap Minat Mahasiswa Akuntansi

Mengikuti Pendidikan Profesi Akuntansi. Prosiding Simposium Nasional Akuntansi VII Bali.

Sudarwan Danim. (2004). Motivasi Kepemimpinan dan efektivitas kelompok. Jakarta: Rineka Cipta.

Sudarmanto, R. Gunawan. (2005). Analisis Regresi Linier Ganda dengan SPSS. Yogyakarta: Graha Ilmu.

Sugiyono. (2003). Metode PenelitianKuantitatif . Bandung : Alfabeta.

Suharsimi Arikunto. (2006). Analisis Regresi. Yogyakarta : Andi Offset.

Sukardi. (1993). Psikologi Pemilihan karier. Jakarta : Rimba Cipta.

Sutrisno Hadi. (2004). Analisis Regresi. Yogyakarta : Andi Offset.

Widyastuti ,Suryaningrum, dan Juliana. (2004). Pengaruh Motivasi terhadap Minat Mahasiswa Akuntansi untuk mengikuti Pendidikan Profesi Akuntansi. Prosiding Simposium Naional Akuntansi VII Bali.

Winardi. (2002). Motivasi dan Pemotivasian Dalam Manajemen. Jakarta: PT Raja Grafindo Perkasa. 
JURNAL NOMINAL / VOLUME II NOMOR II / TAHUN 2013

Yusuf Halim. (2012). Para Akuntan Harus Siap Menghadapi Akuntan Asing.

Diambil dari: http://www.proscg.com/main/news/61/Para-Akuntan-

Harus-Siap-Hadapi-Serbuan-Asing pada tanggal 8 oktober 2012. 